in vivo $32: 1527-1531(2018)$

doi:10.21873/invivo.11410

\title{
Impact of Ethnicity on Somatic Mutation Rates of Pancreatic Adenocarcinoma
}

\author{
NAYRA S. AMARAL ${ }^{1}$, VIVIAN RESENDE ${ }^{1}$, JOSÉ SEBASTIÃO DOS SANTOS ${ }^{2}$, LUIZ FELIPE LIMA ${ }^{1}$, \\ DEBORA C. MORAES ${ }^{1}$, EITAN FRIEDMAN ${ }^{3}$, LUIZ DE MARCO $^{1}$ and LUCIANA BASTOS-RODRIGUES ${ }^{4}$ \\ Departments of ${ }^{1}$ Surgery and ${ }^{4}$ Nutrition, Federal University of Minas Gerais, Belo Horizonte, Brazil; \\ Department of ${ }^{2}$ Surgery and Anatomy, University of Sao Paulo, Ribeirão Preto, Brazil; \\ ${ }^{3}$ The Susanne Levy Gertner Oncogenetics Unit, Chaim Sheba Medical Center, Tel-Hashomer, Israel
}

\begin{abstract}
Background/Aim: Ethnicity has an effect on survival in patients with pancreatic adenocarcinoma (PDAC), which may be reflected in the rate of somatic driver mutations. The Brazilian population represents au extensive interethnic admixture and little is known about the spectrum and rates of somatic driver mutations in Brazilian PDAC cases. Materials and Methods: Direct sequencing of six genes in 23 PDAC cases was performed and the ancestry of patients was determined using a validated panel of ancestry-informative insertion/ deletion DNA polymorphisms. Results: KRAS proto-oncogene (KRAS) was the most commonly mutated gene (60\%). A novel putatively pathogenic mutation in phosphatidylinositol-4,5bisphosphate 3-kinase catalytic subunit alpha (PIK3CA) (c.2948T>A; p.M983K) was identified. Mutations in epidermal growth factor receptor (EGFR) (4\%), PIK3CA (4\%), cyclindependent kinase inhibitor $2 A(C D K N 2 A)(4 \%)$ and TP53 (8\%) were noted, in rates that are less frequent than those reported for other populations. Mutations of B-Raf proto-oncogene, serine/threonine kinase (BRAF) were not present. All individuals with high African ancestral component (allelic frequency, $>0.45)$ exhibited KRAS mutations. Conclusion: Our results highlight the importance of the effect of ethnicity on somatic mutations in Brazilian patients with PDAC.
\end{abstract}

Pancreatic ductal adenocarcinoma (PDAC) is the most common cancer of the pancreas, and a leading cause of

This article is freely accessible online.

Correspondence to: Luiz De Marco, MD, Ph.D., Department of Surgery, Federal University of Minas Gerais, Av Alfredo Balena 190, Room 114, Belo Horizonte 30130-100, Brazil. Tel: +55 3134099134, e-mail: Ldemarco@ufmg.br

Key Words: Pancreatic cancer, KRAS, EGFR, BRAF, PIK3CA, CDKN2A, TP53, ethnicity. cancer-related death (1). The long-term prognosis for patients with PDAC remains dismal with 5-year survival rates ranging from $15-25 \%$. Surgical resection offers the best chance for a cure and remains the mainstay of therapy but only $10-20 \%$ of patients present with resectable disease $(2,3)$.

Pancreatic intraepithelial neoplasm (PanIN) is the most common non-invasive precursor lesion of PDAC (4). Mutations in KRAS proto-oncogene (KRAS) gene occur early in PDAC development and are reportedly detected in $75-100 \%$ of PanIN cases (5), inactivation of cyclindependent kinase inhibitor $2 \mathrm{~A}(C D K N 2 A)$ is an intermediate step in PDAC carcinogenesis and is detected in $30-55 \%$ of PanIN and $92 \%$ of early-stage PDAC (6) and inactivation of TP53 and deleted in pancreatic carcinoma 4/SMAD family member 4 (DPC4/SMAD4) are relatively late-stage molecular events that have rarely been described in PanIN and in $30 \%$ of advanced stage PDAC (4). In addition to KRAS-activating mutations, other genes along the RAS pathway have also been associated with pancreatic cancer pathogenesis such as EGFR and BRAF at rates $2 \%$ (7-9).

Like other tumor types, PDAC incidence and disease course are, in part, dependent on ethnicity (10). The survival rate of US African-American patients with PDAC is $20 \%$ worse compared to US Caucasians and this difference was not attributable to different modes of treatment (11). Likewise, US African-American colorectal cancer cases have higher mortality rates compared with US Caucasians, differences that are not accounted for by socioeconomics, comorbidities, or treatment modalities (12).

The Brazilian population is one of the most genetically heterogeneous populations worldwide as a result of five centuries of admixture between three ethnic groups: Amerindians, Europeans and Africans. It has been demonstrated that skin color in Brazilian individuals is a poor predictor of ethnicity hence the importance of using genetic markers to define population ancestry structure, where ethnicity may affect disease rates or clinical course (13). 
The aim of the present study was to assess the rates of somatic mutations in several key driver pathogenic genes involved in PDAC tumorigenesis and the effect of ancestry analysis on mutational spectrum in patients with PDAC from Southeastern Brazil.

\section{Materials and Methods}

The study cohort encompassed all consenting consecutive patients with PDAC who attended Hospital das Clinicas (Belo Horizonte) and Hospital das Clinicas (Ribeirão Preto), Brazil from June 2011 to May 2016. This study was approved by the University Ethics Committee (\#CAAE 09135912.6.0000.5149). Only participants aged 18 or older were enrolled in this study after signing an informed consent form. Controls (germline DNA) were 96 healthy individuals older than 55 years of age with no previous personal or family history of cancer, randomly recruited from the outpatient clinics in the same medical centers in Belo Horizonte during the same time, using an ethically approved protocol. This group of healthy Brazilian individuals are representative of the ethnic makeup of Southeastern part of Brazil and were used as controls for genomic ancestry.

Tumor samples of PDAC were obtained during surgical procedures and immediately stored at $-80^{\circ} \mathrm{C}$. Before DNA extraction, the samples were microdissected to ensure the highest fraction of tumor cells in the analyzed samples. Genomic DNA was isolated according to a proteinase $\mathrm{K}$-based standard protocol. Exons 2 and 3 of $K R A S$, exon 15 of $B R A F$, exons 18 to 21 of $E G F R$, exon 9 and 20 of $P I K 3 C A$, exons 1 and 2 of $C D K N 2 A$ and exons 4 to 9 of TP53 were amplified by polymerase chain reaction (PCR) with specific primers for each region (primer sequences and PCR conditions available on request). PCR products were purified using Illustra GFX PCR DNA and Gel Band Purification Kit (GE Healthcare, São Paulo, Brazil) following the manufacturer's protocol and visualized on a silver-stained $6.5 \%$ polyacrylamide gel. Sequences were obtained on ABI 3130 Genetic Analyzer (Applied Biosystems, Foster City, CA, USA). Bi-directional sequence data was analyzed using Sequencer 4.9 software (Gene Codes Corporation, Ann Arbor, MI, USA).

Genomic DNA of all pancreatic samples and controls were genotyped with a set of 40 biallelic short insertion/deletion polymorphisms (InDels) (14). Amplicons were sized fractioned using an ABI 3130 DNA sequencer (Applied Biosystems) and analyzed using the GeneMapper ${ }^{\circledR}$ Software, version 3.7 (ThermoFisher Scientific, São Paulo, Brazil). The Structure program, version 2.3, (http://pritch.bsd.uchicago.edu /structure.html) was used to estimate the proportion of European, African and Amerindian bio-geographical ancestry for each individual.

The proportion of European, African and Amerindian biogeographical ancestry of each individual was considered for statistical analysis. Two-tailed Mann-Whitney $U$-test was used for statistical comparisons between cases and controls. Single-marker allelic and genotypic association tests were performed using the Unphased software package version 3.0.12 (www.mrcbsu.cam.ac.uk/personal/ frank/software/unphased/). $p$-Values of 0.05 or less were considered statistically significant.

In order to analyze the deleteriousness of the novel PIK3CA mutation (see Results), a homology model of PIK3CA from its translated protein sequence was obtained. Using psiBLAST
(ProteinDataBank) and Swiss-Model Platform, templates with 99\% and $99.81 \%$ identity to human canonical p110 alpha, PDB 2RDO_A and PDB 3HHM_A, respectively, were obtained allowing us to see how this mutation in exon 20 affected the PIK3CA structure. To correlate this point mutation with a change in the protein's behavior, a model using Modeller (https://salilab.org/modeller/) was built. Pymol software (The PyMOL Molecular Graphics System, Version 1.5.0.4; Educational Pymol; Schördinger, LLC, Mannheim, Germany) was used to generate structural images $(15,16)$. Polyphen-2 (http://genetics.bwh.harvard.edu/pph2/), SIFT (http://sift.bii.astar.edu.sg/) and Mutation Taster (http://www.mutationtaster.org/) software were used to predict the functional effect of amino acid substitution.

\section{Results}

Overall, 23 patients with seemingly operable PDAC were recruited: there were 14 women $(61 \%)$ and nine men $(39 \%)$ with a mean age of 58 years (range $=32-90$ years; $\mathrm{SD}=12.1$ years). Clinical staging was determined according to the American Joint Committee on Cancer (https:// cancerstaging.org/Pages/ default.aspx), with stage IIB being the most prevalent $(62 \%)$, followed by stage IV (14\%), stages III and IIB (9.5\%) and IA $(5 \%)$.

Codon 12 KRAS mutations were detected in 14 samples (60\%): Gly12Val (43\%), Gly12Arg (29\%), Gly12Asp (21\%) and Gly12Sr (7\%). There were no mutations detected in codons 13 and 61 of KRAS.

A P753S missense mutation in exon 19 of EGFR was found in one patient only. In exon 20, the polymorphism rs1050171 [NM_005228.4(EGFR):c.2361G>A; p.Gln787] was identified in 17 samples $(74 \%)$. There were no mutations or polymorphisms in exon 15 of $B R A F$ or in $C D K N 2 A$. No sequence alterations were demonstrated in exons 18 and 21 of EGFR.

In exon 20 of $P I K 3 C A$, a novel heterozygous mutation (g.85992T>A; c.2948T>A; p.M983K) was found. To confirm this novel mutation, exon 20 of PIK3CA was sequenced in 96 healthy control individuals and this alteration was not present in any of the controls. In silico analysis of the M983K mutation was performed using Modeller software (https://salilab.org/modeller/). Prediction of the functional effect of this point mutation indicated its deleteriousness (PolyPhen-2 score=0.999; SIFT score $=0.05$; Mutation Taster score $=95)$, all scores were associated with protein instability (Figure 1).

There were two different mutations in exon 8 of the TP53 gene: R273C and R306*. No pathogenic sequence alterations were found in any other TP53 exons. In exon 4 of TP53, the rs 1042522 polymorphism was present in 18 samples $(78 \%)$.

There were no differences in the proportions of genomic ancestry in Africans, Europeans and Amerindians between patients with PDAC and controls (Figure 2). All four patients with high African ancestral component (allelic frequency $>0.45$ ) had mutations in KRAS. 


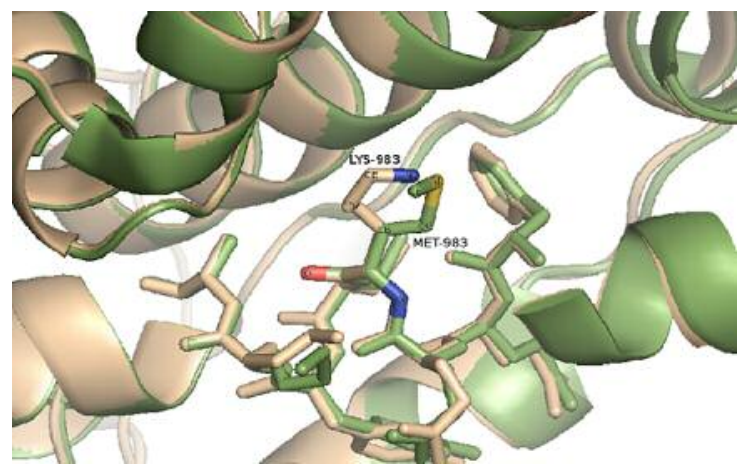

Figure 1. Close-up view of the interface of the phosphatidylinositol-4,5bisphosphate 3-kinase catalytic subunit alpha (PIK3CA) kinase domain, showing the exchange between the mutated residues, in beige, and native residues, in green. The residues MET-983 and LYS-983, which may affect the protein conformation are shown with stick representation.

\section{Discussion}

Somatic activating mutations in $K R A S$, and inactivating $T P 53$ and $C D K N 2 A$ mutations are frequently reported in the transition from PanIN to invasive PDAC (4). The rates of these mutations vary by population and are, in part, determined by ethnicity. In the present study, the rate of mutations in these pivotal PDAC driver genes differ from those of other previously studied populations $(2,17)$. Mutations in codon 12 of KRAS have been reported as the most prevalent genetic alteration in PDAC, ranging from 80$100 \%$ in Caucasians $(2,17,18)$. The rate of $K R A S$ mutation in the current study sample (60\%) was similar to the rate reported in Korean cases (52.2\%) (19). These data are consistent with the notion that the rate of mutation in codon 12 of KRAS vary by ethnicity and that this may in fact partially affect the clinical outcome. Despite the low rate of mutations of EGFR in PDAC (20; Cosmic: Catalogue of Somatic Mutations in Cancer, https://cancer.sanger.ac.uk/ cosmic, accessed 10th September 2018), this receptor is a therapeutic target, as somatic overexpression of the gene product makes the tumor amenable to treatment with monoclonal antibody. In other cancer types (e.g. breast cancer) such treatment was associated with a significant improvement in clinical outcome (20). This is not yet established in PDAC and in fact a recent study failed to show any survival benefit in this tumor type of EGFR-targeted monoclonal antibody (21). Determining EGFR expression and mutational status is still pursued in many cancer types, including PDAC. The rates of EGFR mutations in our cohort as well as mutations in $B R A F$ are consistent with other populations $(22,23)$.

Another mutated gene described herein is PIK3CA (24). Its activation is an important event in cell growth and

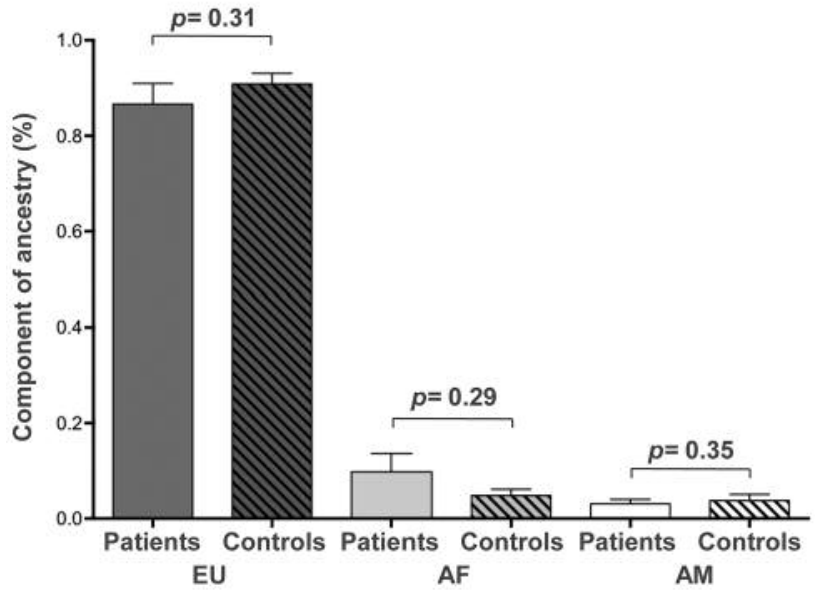

Figure 2. Analysis of the genomic ancestry of patients with pancreatic cancer of this study. EU: European; AF: African; AM: Amerindian; CTRL: control.

survival of several types of cancer (25). In agreement with the rarity of this mutation (less than 4\%) in PDAC cases in previous studies $(23,24,26)$, only one mutation was detected. As far as we are aware, this novel missense mutation (p.M983K) in PIK3CA has not been previously described in PDAC. The in silico analysis indicated that this point mutation is associated with altered protein stability using PolyPhen-2, SIFT and Mutation taster software.

Loss of function or loss of expression of $C D K N 2 A$ is reportedly present in $80 \%$ to $95 \%$ of sporadic PDAC (17). Loss of function or expression of this gene and its product may be mediated by biallelic inactivation (heralded by allelic loss) or methylation in the promoter region (27). Interestingly, no somatic mutations were observed in $C D K N 2 A$ in our study, a finding in contrast with other reports showing rates of $17 \%$ to $34 \%(2,28)$. These differences in specific gene-related mutations between ethnically diverse populations may in part account for the differences in age at diagnosis and disease course and outcome.

The $r$ s 1042522 polymorphism of the TP53 gene has been associated with increased risk for developing pancreatic cancer (29) and was present in $78 \%$ of our samples. However, despite findings that TP53 mutations are present in pancreatic cancer $(2,30)$, only two mutations $(9 \%)$, R273C and R306*, were found in our samples.

\section{Conclusion}

Our results highlight the possible impact of ethnic heterogeneity on somatic genetic mutations in PDAC, and that this, in turn, may affect ethnic-related differences may impact outcome and therapeutic response. 


\section{Conflicts of Interest}

The Authors declare that they have no conflicts of interest regarding this study.

\section{Acknowledgements}

The Authors are grateful to Ms Flavia Passos for help. This work was partially funded by Conselho Nacional de Desenvolvimento Científico e Tecnológico (CNPq \# 405053/2013-4) and Fundação de Amparo à Pesquisa de Minas Gerais (FAPEMIG \# CDS- RED00019-16).

\section{References}

1 Coupland VH, Kocher HM, Berry DP, Allum W, Linklater KM, Konfortion J, Moller H and Davies EA: Incidence and survival for hepatic, pancreatic and biliary cancers in England between 1998 and 2007. Cancer Epidemiol 36: e207-e214, 2012.

2 Ryan DP, Hong TS and Bardeesy N: Pancreatic adenocarcinoma. N Engl J Med 371: 1039-1049, 2014.

3 Stark AP, Sacks GD, Rochefort MM, Donahue TR, Reber HA, Tomlinson JS, Dawson DW, Eibl G and Hines OJ: Long-term survival in patients with pancreatic ductal adenocarcinoma. Surgery 159: 1520-1527, 2016.

4 Aguirre AJ and Collisson EA: Advances in the genetics and biology of pancreatic cancer. Cancer J 23: 315-320, 2017.

5 Waddell N, Pajic M, Patch AM, Chang DK, Kassahn KS, Bailey P, Johns AL, Miller D, Nones K, Quek K, Quinn MC, Robertson AJ, Fadlullah MZ, Bruxner TJ, Christ AN, Harliwong I, Idrisoglu S, Manning S, Nourse C, Nourbakhsh E, Wani S, Wilson PJ, Markham E, Cloonan N, Anderson MJ, Fink JL, Holmes O, Kazakoff SH, Leonard C, Newell F, Poudel B, Song S, Taylor D, Waddell N, Wood S, Xu Q, Wu J, Pinese M, Cowley MJ, Lee HC, Jones MD, Nagrial AM, Humphris J, Chantrill LA, Chin V, Steinmann AM, Mawson A, Humphrey ES, Colvin EK, Chou A, Scarlett CJ, Pinho AV, Giry-Laterriere $M$ and Rooman I, Samra JS, Kench JG, Pettitt JA, Merrett ND, Toon C, Epari K, Nguyen NQ, Barbour A, Zeps N, Jamieson NB, Graham JS, Niclou SP, Bjerkvig R, Grützmann R, Aust D, Hruban RH, Maitra A, Iacobuzio-Donahue CA, Wolfgang CL, Morgan RA, Lawlor RT, Corbo V, Bassi C, Falconi M, Zamboni G, Tortora G, Tempero MA; Australian Pancreatic Cancer Genome Initiative, Gill AJ, Eshleman JR, Pilarsky C, Scarpa A, Musgrove EA, Pearson JV, Biankin AV and Grimmond SM: Whole genomes redefine the mutational landscape of pancreatic cancer. Nature 518: 495-501, 2015.

6 Wilentz RE, Geradts J, Maynard R, Offerhaus GJ, Kang M, Goggins M, Yeo CJ, Kern SE and Hruban RH: Inactivation of the p16 (INK4A) tumor-suppressor gene in pancreatic duct lesions: Loss of intranuclear expression. Cancer Res 58: 47404744, 1998.

7 Bailey P, Chang DK, Nones K, Johns AL, Patch AM, Gingras MC, Miller DK, Christ AN, Bruxner TJ, Quinn MC, Nourse C, Murtaugh LC, Harliwong I, Idrisoglu S, Manning S, Nourbakhsh E, Wani S, Fink L, Holmes O, Chin V, Anderson MJ, Kazakoff S, Leonard C, Newell F, Waddell N, Wood S, Xu Q, Wilson PJ, Cloonan N, Kassahn KS, Taylor D, Quek K, Robertson A, Pantano L, Mincarelli L, Sanchez LN, Evers L, Wu J, Pinese M,
Cowley MJ, Jones MD, Colvin EK, Nagrial AM, Humphrey ES, Chantrill LA, Mawson A, Humphris J, Chou A, Pajic M, Scarlett CJ, Pinho AV, Giry-Laterriere M and Rooman I, Samra JS, Kench JG, Lovell JA, Merrett ND, Toon CW, Epari K, Nguyen NQ, Barbour A, Zeps N, Moran-Jones K, Jamieson NB, Graham JS, Duthie F, Oien K, Hair J, Grützmann R, Maitra A, IacobuzioDonahue CA, Wolfgang CL, Morgan RA, Lawlor RT, Corbo V, Bassi C, Rusev B, Capelli P, Salvia R, Tortora G, Mukhopadhyay D, Petersen GM; Australian Pancreatic Cancer Genome Initiative, Munzy DM, Fisher WE, Karim SA, Eshleman JR, Hruban RH, Pilarsky C, Morton JP, Sansom OJ, Scarpa A, Musgrove EA, Bailey UM, Hofmann O, Sutherland RL, Wheeler DA, Gill AJ, Gibbs RA, Pearson JV, Waddell N, Biankin AV and Grimmond SM: Genomic analyses identify molecular subtypes of pancreatic cancer. Nature 531: 47-52, 2016.

8 Wang J, Dumartin L, Mafficini A, Ulug P, Sangaralingam A, Alamiry NA, Radon TP, Salvia R, Lawlor RT, Lemoine NR, Scarpa A, Chelala C and Crnogorac-Jurcevic T: Splice variants as novel targets in pancreatic ductal adenocarcinoma. Sci Rep 7: 2980, 2017.

9 Dreyer SB, Jamieson NB, Upstill-Goddard R and Bailey PJ, McKay CJ; Australian Pancreatic Cancer Genome Initiative, Biankin AV and Chang DK: Defining the molecular pathology of pancreatic body and tail adenocarcinoma. Br J Surg 105: e183-e191, 2018.

10 Henderson BE, Lee NH, Seewaldt V and Shen H: The influence of race and ethnicity on the biology of cancer. Nat Rev Cancer 12: 648-653, 2012.

11 Singal V, Singal AK and Kuo YF: J. Racial disparities in treatment for pancreatic cancer and impact on survival: A population-based analysis. J Cancer Res Clin Oncol 138: 715-722, 2012.

12 Augustus GJ and Ellis NA: Colorectal cancer disparity in African Americans: risk factors and carcinogenic mechanisms. Am J Pathol 188: 291-303, 2018.

13 Kehdy FS, Gouveia MH, Machado M, Magalhães WC, Horimoto AR, Horta BL, Moreira RG, Leal TP, Scliar MO, Soares-Souza GB and Rodrigues-Soares F, Araújo GS, Zamudio R, Sant Anna HP, Santos HC, Duarte NE, Fiaccone RL, Figueiredo CA, Silva TM, Costa GN, Beleza S, Berg DE, Cabrera L, Debortoli G, Duarte D, Ghirotto S, Gilman RH, Gonçalves VF, Marrero AR, Muniz YC, Weissensteiner H, Yeager M, Rodrigues LC, Barreto ML, Lima-Costa MF, Pereira AC, Rodrigues MR, Tarazona-Santos E; Brazilian EPIGEN Project Consortium: Origin and dynamics of admixture in Brazilians and its effect on the pattern of deleterious mutations. Proc Natl Acad Sci USA 112: 8696-8701, 2015.

14 Bastos-Rodrigues L, Pimenta JR and Pena SD: The genetic structure of human populations studied through short insertiondeletion polymorphisms. Ann Hum Genet 70: 658-665, 2006.

15 Arnold K, Bordoli L, Kopp J and Schwede T: The SWISSMODEL Workspace: A web-based environment for protein structure homology modelling. Bioinformatics 22: 195-201, 2006.

16 Mandelker D, Gabelli SB, Schmidt-Kittler O and Zhu J, Cheong I, Huang CH, Kinzler KW, Vogelstein B and Amzel LM: A frequent kinase domain mutation that changes the interaction between PI3Kalpha and the membrane. Proc Natl Acad Sci USA 106: 16996-17001, 2009.

17 Singh P, Srinivasan R and Wig JD: Major molecular markers in pancreatic ductal adenocarcinoma and their roles in screening diagnosis, prognosis, and treatment. Pancreas 40: 644-652, 2011. 
18 Scakpa A, Capelli P, Villanueva A, Zamboni G, Lluì F, Accolla R, Mariuzzi G, Capellà G: Pancreatic cancer in Europe: Ki-Ras gene mutation pattern shows geographical differences. Int $\mathrm{J}$ Cancer 57: 167-171, 1994.

19 Kim ST, Lim do H, Jang KT, Lim T, Lee J, Choi YL, Jang HL, Yi JH, Baek KK, Park SH, Park YS, Lim HY, Kang WK and Park JO: Impact of KRAS mutations on clinical outcomes in pancreatic cancer patients treated with first-line gemcitabinebased chemotherapy. Mol Cancer Ther 10: 1993-1999, 2011.

20 Okamoto I, Morita S, Tashiro N, Imamura F, Inoue A, Seto T, Yamamoto N, Ohe Y, Nakagawa K and Fukuoka M: Real world treatment and outcomes in EGFR mutation-positive non-small cell lung cancer: Long-term follow-up of a large patient cohort Lung Cancer 117: 14-19, 2018.

21 Middleton G, Palmer DH, Greenhalf W, Ghaneh P, Jackson R, Cox T, Evans A, Shaw VE, Wadsley J, Valle JW, Propper D, Wasan H, Falk S, Cunningham D, Coxon F, Ross P, Madhusudan S, Wadd N, Corrie P, Hickish T, Costello E, Campbell F, Rawcliffe C and Neoptolemos JP: Vandetanib plus gemcitabine versus placebo plus gemcitabine in locally advanced or metastatic pancreatic carcinoma (ViP): A prospective, randomised, double-blind, multicentre phase 2 trial. Lancet Oncol 18: 486-499, 2017.

22 Immervoll H, Hoem D, Kugarajh K, Steine SJ and Molven A: Molecular analysis of the EGFR-RAS-RAF pathway in pancreatic ductal adenocarcinomas: lack of mutations in the $B R A F$ and EGFR genes. Virchows Arch 448: 788-796, 2006.

23 Weiss GA, Rossi MR, Khushalani NI, Lo K, Gibbs JF, Bharthuar A, Cowell JK and Iyer R: Evaluation of phosphatidylinositol-3kinase catalytic subunit (PIK3CA) and epidermal growth factor receptor EGFR gene mutations in pancreaticobiliary adenocarcinoma. J Gastrointest Oncol 4: 20-29, 2013.

24 Witkiewicz AK, McMillan EA, Balaji U, Baek G, Lin WC, Mansour J, Mollaee M, Wagner KU, Koduru P, Yopp A, Choti MA, Yeo CJ, McCue P, White MA and Knudsen ES: Wholeexome sequencing of pancreatic cancer defines genetic diversity and therapeutic targets. Nat Commun 6: 6744, 2015.
25 Janku F, Lee JJ, Tsimberidou AM, Hong DS, Naing A, Falchook GS, Fu S, Luthra R, Garrido-Laguna I and Kurzrock R: PIK3CA mutations frequently coexist with $R A S$ and $B R A F$ mutations in patients with advanced cancers. PLoS One 6: e22769, 2011.

26 Kwon MJ, Kim JW, Jung JP, Cho JW, Nam ES, Cho SJ, Kim JS, Park HR, Min SK, Seo J, Min KW, Kim DH and Jeon JY: Low incidence of KRAS, BRAF, and PIK3CA mutations in adenocarcinomas of the ampulla of Vater and their prognostic value. Hum Pathol 50: 90-100, 2016.

27 Oshima M, Okano K, Muraki S, Haba R, Maeba T, Suzuki Y and Yachida S: Immunohistochemically detected expression of 3 major genes (CDKN2A/p16, TP53, and SMAD4/DPC4) strongly predicts survival in patients with resectable pancreatic cancer. Ann Surg 258: 336-346, 2013.

28 Rachakonda PS, Bauer AS, Xie H, Campa D, Rizzato C, Canzian F, Beghelli S, Greenhalf W, Costello E, Schanne M, Heller A, Scarpa A, Neoptolemos JP, Werner J, Büchler M, Hoheisel JD, Hemminki K, Giese N and Kumar R: Somatic mutations in exocrine pancreatic tumors: association with patient survival. PLoS One 8: e60870, 2013.

29 Naccarati A, Pardini B, Polakova V, Smerhovsky Z, Vodickova L, Soucek P, Vrana D, Holcatova I, Ryska M and Vodicka P: Genotype and haplotype analysis of TP53 gene and the risk of pancreatic cancer: an association study in the Czech Republic. Carcinogenesis 31: 666-670, 2010.

30 Ghaneh P, Costello E and Neoptolemos JP: Biology and management of pancreatic cancer. Gut 56: 1134-1152, 2007.
Received July 26, 2018

Revised September 11, 2018

Accepted September 12, 2018 